\title{
Faktor - Faktor yang Mempengaruhi Pendapatan Harian Pedagang Ikan di Kefamenanu Kabupaten Timor Tengah Utara
}

Adeline Norawati Hutapea ${ }^{a}$

${ }^{a}$ Fakultas Pertanian, Universitas Timor, Kefamenanu, TTU - NTT, 85613, Indonesia.

\section{Article Info}

\section{Article history:}

Received 27 Agustus 2015

Received in revised form 1 September 2015 Accepted 29 September 2015

\section{Keywords:}

Pedagang Ikan

Pendapatan Harian

Kefamenanu

\section{Pendahuluan}

Sektor informal telah menjadi alternatif pilihan bagi sebagaian masyarakat di Kota Kefamenanu sebagai sumber penghidupannya. Tingginya standar pengetahuan dan keterampilan, semakin sulit bagi masyarakat untuk berkompetisi memperoleh pekerjaan di sektor formal. Namun tututan untuk bertahan hidup, menjadikan sebagian masyarakat lebih kreatif, bahkan mereka dengan keterampilan dan modal yang terbatas bisa menciptakan lapangan pekerjaan sendiri, yaitu menjadi pedagang ikan

Sesuai dengan hukum permintaan dan penawaran, sektor perdagangan ikan memiliki prospek ekonomis sebagai salah satu sumber pendapatan masyarakat. Seiring dengan pertumbuhan penduduk dan semakin meningkatkan kesadaran masyarakat untuk mengkonsumsi ikan, maka permintaan ikan di Kota Kefamenanu juga semakin tinggi. Sedangkan dari aspek penawaran, pasokan ikan masyarakat Kota Kefamenanu bersumber dari tiga lokasi, yaitu Kupang, Wini dan Atapupu, sehingga relatif bisa menjaga ketersediaan dan stabilitas harga ikan bagi masyarakat. Walaupun tidak dipungkiri pada bulan-bulan tertentu pasokan ikan mengalami fluktuasi, namun itu lebih disebabkan karena faktor cuaca, bukan karena aspek rantai distribusi pemasaran ikan

Peluang pasar tersebut, menjadi salah satu pertimbangan bagi masyarakat untuk berprofesi sebagai pedagang ikan. Berdasarkan data Badan Pusat Statistik Kabupaten Timor Tengah Utara (2015), tercatat bahwa sampai dengan tahun 2014 jumlah pedagang ikan di Kota Kefamenanu sebanyak 74 pedagang, yang terdiri dari dua kategori yaitu pedagang ikan menetap dan keliling. Pedagang yang menetap berdagang di tiga lokasi yaitu, Pasar Baru, Pasar Lama dan Terminal, sedangkan pedagang ikan keliling terdiri dari dua jenis, yaitu berkeliling berjalan kaki dengan gerobak dorong dan dengan sepeda motor.

Kenaikan jumlah pedagang ikan di Kota Kefamenanu dalam tiga tahun terakhir bisa diinterpretasikan bahwa sektor ini cukup menjanjikan sebagai salah satu sumber penghidupan masyarakat. Namun demikian, asumsi ini perlu pembuktian secara ilmiah apakah hal tersebut memang demikian. Menginga pedagang ikan tersebut rata-rata berpendidikan rendah dan dalam berusaha belum menerapkan manajemen modern. Selain itu, aspek modal yang relatif terbatas, jumlah jam kerja, sarana transportasi dan ketergantungan pasokan dan harga ikan yang dipatok papalele bisa berpengaruh terhadap pendapatan mereka Dengan demikian, tingginya permintaan ikan di pasaran tidak serta merta meningkatkan pendapatan pedagang ikan tersebut. Dalam konteks ini, peneliti hanya menganalisis faktor-faktor yang mempengaruhi pendapatan pedagang ikan di Kota Kefamenanu, yaitu modal, harga ikan di tingkat papalele dan jumlah jam kerja mengingat terbatasnya waktu yang tersedia. Berdasarkan permasalahan tersebut, maka penelitian ini bertujuan untuk mengetahui pendapatan harian pedagang ikan di Kota Kefamenanu dan faktor-faktor yang mempengaruhi pendapatan harian pedagang ikan di Kota Kefamenanu.

\section{Metode}

Pengambilan sampel menggunakan metode simple random sampling sesuai petunjuk Sugiyono, 2007. Variabel bebas dalam penelitian ini meliputi modal, harga ikan, jumlah jam kerja dan biaya operasional sedangkan variabel terikat adalah pendapatan pedagang ikan di Kota Kefamenanu. Pengumpulan data dilakukan menggunakan metode berupa wawancara, observasi, dokumentasi dan questioner. Pengamatan dan konsep pengukuran meliputi 1) Identitas responden, meliputi; umur, jenis kelamin, pendidikan, jumlah tanggungan keluarga, dan pengalaman; 2) Biaya-biaya, meliputi; biaya tetap ( fixed cost) dan biaya tidak tetap (variabel cost) (Samuelson dan Nordhaus, 2002), dan; 3) Pendapatan harian (Rp). Ada dua model analisis data yang digunakan dalam penelitian ini yakni 1 Untuk mengetahui gambaran umum pendapatan harian pedagang ikan, menggunakan metode analisis deskriptif, peneliti mendeskripsikan data yang yang diperoleh di lapangan, dan; 2) Untuk mengetahui faktor-faktor yang mempengaruhi pendapatan harian pedagang ikan di Kota Kefamenanu peneliti menggunakan teknik analisis regresi berganda dengan bantuan software SPSS (Priyatno 2013).

\section{Hasil dan Pembahasan}

3.1 Identitas Responden

Sebagian besar umur responden berada pada kelompok usia produktif, sebanyak 19 responden $(45,23 \%)$ berusia antara 21-30 tahun, diikuti pada kelompok umur 31-40 tahun sebanyak 12 responden (28,57\%). Namun demikian terdapat satu responden $(2,39 \%)$ yang termasuk dalam kelompok diluar usia produktif. Sedangkan berdasarkan jenis kelamin, sebagian besar atau 40 pedagang $(95,24 \%)$ berjenis kelamin laki-laki, sisanya 2 pedagang $(4,76 \%)$ merupakan wanita. Rata-rata tingkat pendidikan responden termasuk rendah, dari 42 responden sebanyak 22 pedagang $(52,38 \%)$ berpendidikan SD, diikuti dengan pedagang yang berpendidikan SMU sebanyak 12 pedagang $(28,57 \%)$, sedangkan yang berpendidikan SMP sebanyak 8 pedagang $(19,05 \%)$. Sedangkan dari pengalaman atau lamanya berdagang, sebanyak 22 responden $(52,38 \%)$ relatif belum lama berdagang karena baru 1-5 tahun berdagang, sedangkan yang memiliki pengalaman selama 6-10 tahun sebanyak 12 responden $(28,57 \%)$, sedangkan yang lebih dari 16 tahun berdagang ikan ada satu pedagang $(2,39 \%)$.

\subsection{Pendapatan}

Menurut Samuelson dan Nordhaus (2002) pendapatan merupakan jumlah seluruh uang yang diterima oleh seseorang atau rumah tangga selama jangka waktu tertentu. Pendapatan harian pedagang ikan di Kota Kefamenanu dalam penelitian ini dipengaruhi oleh modal, harga ikan, jam kerja dan biaya operasional.

Modal adalah barang atau uang yang secara bersama-sama dengan faktor produksi, tanah dan tenaga kerja menghasilkan barang yang baru. Salah satu faktor penting dalam perdagangan adalah modal, karena kecukupan modal berpengaruh terhadap keberlanjutan usaha (Mubyarto, 1998). Modal digunakan para pedagang untuk ikan mengambil 'jatah' dari papalele, selanjutnya mereka menjualnya ke konsumen. Berdasarkan hasil penelitian menunjukkan bahwa sebanyak 19 pedagang ikan $(45,24 \%)$ memiliki rata-rata modal antara Rp. 600.000 - Rp. 1.000 .000 , sebanyak 10 pedagang ikan $(23,80 \%)$ merupakan padagang ikan yang cukup besar, karena memiliki modal lebih dari Rp. 1.000 .000 , sedangkan sisanya $(30,96 \%)$ hanya memiliki modal kurang dari Rp.500.000.

Harga ikan dalam konteks tulisan ini adalah harga ikan yang terjual. Berdasarkan hasil penelitian menunjukkan bahwa para pedagang ikan di Kota Kefamenanu telah memiliki standar harga yang telah disepakati. Hal ini dipengaruhi oleh besaran harga ikan di tingkat papalele juga seragam. Secara umum, ikan dijual dengan harga Rp. 10.000 - Rp. 50.000. Harga jual ikan kombong Rp. 20.000/6 ekor. Ikan burik Rp. 20.000/8 ekor, ikan tembang Rp. 10.000/8 ekor dan ikan cakalang Rp 50.000/ekor.

Jam kerja merupakan lamanya pedagang ikan melakukan aktivitas perdagangannya dalam satu hari. Faktor jam kerja pedagang ikan mempengaruhi pendapatan usaha, semakin lama waktu yang digunakan dalam bekerja, maka memiliki kecenderungan bahwa pedagang ikan memiliki pendapatan yan semakin tinggi. Berdasarkan hasil penelitian, menunjukkan bahwa jam kerja antara 7-13 jam sama dengan jam kerja 7-10 jam, yaitu sebanyak 21 pedagang $(50 \%)$.

Salah satu faktor yang juga berpengaruh terhadap pendapatan adalah biaya operasional, yang biasanya digunakan untuk pembelian parang, pisau, papan iris, ember/kumbang, bensin, boks, kantong plastik, es, makanan dan minuman serta rokok. Berikut adalah jumlah biaya operasional dari para pedagang. Berdasarkan hasil penelitian menunjukkan bahwa pengeluaran untuk besaran biaya operasional antara Rp. 410.000 - Rp. 500.000 sebanyak 36 responden $(85,71 \%)$

Berdasarkan hasil perhitungan, pendapatan para pedagang ikan $\mathrm{d}$ Kefamenanu sebesar Rp. 25.570.000, yaitu selisih antara total penerimaan (TR) sebesar Rp. 45.150.000 dengan total biaya (TC) sebesar Rp. 17.510.000. Dengan demikian, pendapatan rata-rata harian pedagang ikan sebesar Rp. 91.320 .

3.3 Analisis Faktor-Faktor yang Mempengaruhi Pendapatan Pedagang Ikan

Faktor-faktor yang mempengaruhi pendapatan harian pedagang ikan meliputi modal $\left(\mathrm{X}_{1}\right)$, harga ikan $\left(\mathrm{X}_{2}\right)$, jam kerja $\left(\mathrm{X}_{3}\right)$ dan biaya operasional $\left(\mathrm{X}_{4}\right)$ 
Berdasarkan perhitungan regresi dengan bantuan software SPSS diperoleh hasil seperti pada Tabel 1

Tabel 1. Ringkasan Model

\begin{tabular}{lrrrr}
\hline Model & $\mathrm{r}$ & R Square & Adjusted R Square & Std. Error of the Estimate \\
\hline $\mathrm{Y}$ & $0,582^{\mathrm{a}}$ & 0,339 & 0,268 & 59178,464 \\
\hline
\end{tabular}

Predictors: (Constant), Biaya Operasional (X4), Modal (X1), Jumlah Jam Kerja (X3), Harga Ikan (X2)

Data Tabel 1. menunjukkan bahwa nilai koefisien relasi (R) adalah 0,582, yang menunjukkan bahwa hubungan antara variabel $\mathrm{X}$ dan $\mathrm{Y}$ berada pada kategori sedang, dan persentase pengaruh variabel independen $(\mathrm{X})$ terhadap variabel dependen $(\mathrm{Y})$ yang ditunjukkan dengan koefisien determinasi $(\mathrm{R}$ Square) sebesar 0,339 (33,9\%), dengan demikian $66,1 \%$ dipengaruhi oleh faktor lain di luar variabel $\mathrm{X}_{1}, \mathrm{X}_{2}, \mathrm{X}_{3}$ dan $\mathrm{X}_{4}$

Selanjutnya dilakukan uji untuk mengetahui sejauh mana pengaruh variabel $\mathrm{X}$ terhadap Y baik secara bersama maupun sendiri-sendiri dengan uji t dan taraf signifikansi 0,05 atau $5 \%$.

Hasil analisis dengan bantuan software SPSS sesuai petunjuk Priyanto (2013) terlihat pada Tabel 2. Uji F (uji simultan) digunakan untuk mengetahui apakah variabel bebas secara bersama-sama berpengaruh secara nyata atau tidak terhadap variable terikat, dengan rumusan hipotesis 1) Ho : variabel bebas tidak berpengaruh secara bersama-sama terhadap variabel terikat; 2) Ha : variabel bebas berpengaruh secara bersama-sama terhadap variabel terikat.

Tabel 2. Uji F

\begin{tabular}{lccccc}
\hline \multicolumn{1}{c}{ Model } & Sum of Squares & Df & Mean Square & F & Sig. \\
\hline Regression & $6,649 \mathrm{E} 10$ & 4 & $1,662 \mathrm{E} 1$ & 4,746 & $0,003^{\mathrm{a}}$ \\
Residual & $1,296 \mathrm{E} 11$ & 37 & $3,502 \mathrm{E} 9$ & & \\
Total & $1,961 \mathrm{E} 11$ & 41 & & & \\
\hline
\end{tabular}

Predictors: (Constant), Biaya Operasional (X4), Modal (X1), Jumlah Jam Kerja (X3), Harga Ikan (X2), Dependent Variable: Pendapatan (Rp)

Berdasarkan data pada Tabel 2. diperoleh $\mathrm{F}_{\text {hitung }}$ 4,746 dan nilai $p$-value 0,000 . Nilai yang diperoleh ini kemudian diuji dengan $\mathrm{F}_{\text {tabel }}$ untuk probabilitas 0,05 . Nilai $\mathrm{F}_{\text {tabel }}$ diperoleh dengan menggunakan tabel $\mathrm{F}$ dengan derajat bebas $\mathrm{d}$ Residual (sisa) yaitu 37 sebagai df Penyebut dan df Regression (perlakuan) yaitu 4 sebagai df pembilang, sehingga diperoleh nilai $\mathrm{F}_{\text {tabel }} 2,63$. Berdasarkan data tersebut dapat dilihat bahwa nilai $\mathrm{F}_{\text {hitumg }} 4,746>\mathrm{F}_{\text {tabel }} 2,63$ atau nilai probabilitas $0,05>p$-value 0,00. Jadi Ha diterima dan Ho ditolak. Hal ini menunjukkan bahwa dengan taraf signifikansi 5\% maka modal, harga ikan, jumlah jam kerja dan biaya operasional secara bersama-sama berpengaruh terhadap pendapatan pedagang ikan.

Selanjutnya untuk mengetahui persentase pengaruh variabel $X_{1}, X_{2}, X_{3}$ dan $\mathrm{X}_{4}$ terhadap variabel $\mathrm{Y}$ menggunakan perhitungan regresi dengan bantuan software SPPS seperti pada Tabel 3.

Tabel 3. Perhitungan Regresi

\begin{tabular}{|c|c|c|c|c|c|}
\hline \multirow{2}{*}{ Model } & \multicolumn{2}{|c|}{ Unstandardized Coefficients } & \multirow{2}{*}{$\begin{array}{c}\text { Standardized Coefficients } \\
\text { Beta }\end{array}$} & \multirow{2}{*}{$\mathrm{T}$} & \multirow{2}{*}{ Sig. } \\
\hline & $\mathrm{B}$ & Std. Error & & & \\
\hline (Constant) & 97307,009 & 142852,083 & & 0,681 & 0,500 \\
\hline Modal & 0,028 & 0,011 & 0,359 & 2,607 & 0,013 \\
\hline Harga Ikan & 0,006 & 0,006 & 0,159 & 1,100 & 0,278 \\
\hline Jumlah Jam Kerja & 14017,603 & 5715,404 & 0,355 & 2,453 & 0,019 \\
\hline Biaya Operasional & $-0,423$ & 0,321 & $-0,186$ & $-1,317$ & 0,196 \\
\hline
\end{tabular}

Berdasarkan Tabel 3. selanjutnya dilakukan uji t untuk mengetahui pengaruh masing-masing variabel $\mathrm{X}$ terhadap $\mathrm{Y}$ (parsial) yang diambil dari kolom $\mathrm{T}$ dan kolom Sig. dengan kriterian 1) jika nilai Sig. > 0,05 berarti tidak ada hubungan linear antara kedua variabel yang diuji; 2) jika nilai Sig. $<0,05$ berarti ada hubungan linear antara kedua variabel yang diuji.

Nilai Sig. untuk variabel modal 0,013, nilai ini lebih kecil dari 0,05 (Sig < 0,05). Dengan demikian, pada tingkat signikansi $5 \%$ ternyata modal berpengaruh secara nyata terhadap pendapatan pedagang ikan. Hal ini disebabkan besar kecilnya modal para pedagang ikan akan mempengaruhi volume atau jatah ikan yang diperoleh dari papalele. Nilai Sig. untuk variabel harga ikan 0,278 , nilai ini lebih besar dari 0,05 (Sig > 0,05). Dengan demikian, pada kepercayaan 5\% ternyata harga ikan tidak berpengaruh secara nyata terhadap pendapatan pedagang ikan. Hal ini disebabkan karena adanya keseragaman harga ikan di tingkat pedagang sesuai dengan jenisnya, sehingga perbedaannya terletak pada volume penjualan ikan untuk masing-masing pedagang, semakin banyak ikan yang terjual, semakin tinggi pula pendapatan para pedagang ikan tersebut. Nilai Sig. untuk variabel jumlah jam kerja 0,019, nilai ini lebih kecil dari 0,05 (Sig > 0,05). Dengan demikian, pada taraf signifikansi $5 \%$ ternyata jumlah jam kerja berpengaruh secara nyata terhadap pendapatan pedagang, karena semakin lama pedagang ikan berjualan peluang ikan yang akan terjual akan semakin banyak pula dan hal ini akan memberikan kontribusi terhadap peningkatan pendapatan pedagang ikan tersebut. Nilai Sig. untuk variabel biaya operasional 0,196, nilai ini lebih besar dari 0,05 ( $\mathrm{Sig}>0,05$ ). Dengan demikian, tidak ada hubungan linear antara variabel jumlah jam kerja dengan variabel pendapatan. Atau dengan kata lain, pada tingkat kepercayaan 5\% ternyata biaya operasional tidak berpengaruh secara nyata terhadap pendapatan harian pedagang ikan. Hal ini disebabkan, karena biaya operasional yang dikeluarkan oleh pedagang ikan setiap harinya sama dan biaya ini sudah ditentukan dan diberikan oleh pemilik ikan (papalele) di luar penjualan ikan.

Dari hasil analisis tersebut, dapat disimpulkan bahwa hipotesis yang dibangun yakni bahwa faktor modal, harga ikan, jumlah jam kerja dan biaya operasional berpengaruh terhadap pendapatan harian pedagang ikan mempunyai dasar yang cukup kuat. Berdasarkan uji hipotesis, harga ikan dan biaya operasional tidak berpengaruh secara nyata terhadap pendapatan pedagang ikan, sedangkan modal dan dan jumlah jam kerja berpengaruh secara signifikan terhadap pendapatan harian pedagang ikan di Kefamenanu.

\section{Simpulan}

Pendapatan harian pedagang ikan di Kefamenanu secara umum bersifat fluktuatif, tergantung pada pemilihan lokasi berjualan dan kreatifitas dalam pemasaran. Rata-rata pendapatan harian pedagang ikan berkisar antara Rp. 50.000 - Rp. 300.000, dengan harga ikan yang seragam di tingkat pedagang sesuai dengan jenis ikannya, maka disparitas pendapatan terletak pada volume penjualan ikan untuk masing-masing pedagang. Berdasarkan uji hipotesis, nilai sig variabel modal 0,013 dan nilai sig variabel jumlah jam kerja 0,019 , nilai ini lebih kecil dari 0,05 (Sig > 0,05). Dengan demikian, pada tingkat signikansi 5\% ternyata modal dan jumlah jam kerja berpengaruh secara nyata terhadap pendapatan pedagang ikan. Sedangkan nilai sig variabel harga ikan 0,278 dan nilai sig variabel biaya operasional 0,196, nilai ini lebih besar dari 0,05 ( $\mathrm{Sig}>$ 0,05). Dengan demikian, pada tingkat kepercayaan 5\% tidak ada hubungan linear antara variabel harga ikan dan biaya operasional terhadap pendapatan harian pedagang ikan.

\section{Pustaka}

Badan Pusat Statistik Kabupaten Timor Tengah Utara. 2015. Timor Tengah Utara dalam Angka. Badan Pusat Statistik. Kefamenanu.

Mubyarto. 1998. Pembangunan dan Pemberdayaan Masyarakat. Yogyakarta. Pustaka Pelajar.

Priyatno. 2013. Analisi Korelasi, Regresi dan Multivariate Dengan SPSS. Gava Media Jogjakarta.

Samuelson dan Nordhaus. 1993. Perekonomian Indonesia, edisi 2, Jakarta. Erlangga.

Sugiyono. 2007. Metode Penelitian Kuantitatif Kualitatif. Bandung. Alfabeta. 